\title{
A Study on BOE's Private Placement Risk and the Tunneling Behavior of Stakeholders
}

\author{
Wei Wang1), Shanyue Jin2), Songjuk Kim³)
}

\begin{abstract}
The issue of private placement risks and tunneling behavior associated with Chinese enterprise stakeholders is a matter of greater concern in academic and industry. On the basis of Agency Theory and Asymmetric Information Theory, the study adopts the case-study method-taking BOE(Beijing Over East) to investigate the refinancing risk and tunneling behavior in 2014. The BOE case is a very typical case in the field of a private placement of Chinese companies. The findings indicate that the risk from private placement varies among different types of stakeholders (large stockholders, minority stockholders, new investors, management, etc.). Also, the tunneling behavior mainly manifests as earnings management, private placement pricing, subscription method, management subscription, and so on. Suggestions for this study are as follows: First, choose a financing and development mode that fits the company, maintain steady funding sources, and set a high-quality offering target. Second, respond by consolidating the company's strengths and improve its all-around abilities, such as innovation, competitiveness, and profit capability. Third, choose the right timing to issue the private placement. Fourth, take every opportunity to improve the confidence of the market and the related investors.
\end{abstract}

Keywords: Private Placement, Risk, Tunneling, Stakeholders, BOE

\section{Introduction}

Private placement has become a favored method of refinancing among listed Chinese companies ever since it came into effect in China in May 2006[1]. With both the number of private placements and the scale of such financing achieving record highs in recent years, it has become the preferred equity refinancing approach for listed companies in China. In 2017, 92.9\% of Chinese listed companies achieved their financing goals via private placement, raising a

Received(April 15, 2020), Review Result(1st: June 1, 2020, 2nd: July 24, 2020), Accepted(August 28, 2020)

1) (Chaiman and CEO) 311203 Zhejiang Rongqing Engineering Co., Ltd., $7^{\text {th }}$ floor, Jinmao Building, No. 398, Shinxinzhong Road, Xiaoshan District, Hangzhou, Zhejiang, China email: 291906652@qq.com

2) (Associate Professor, Corresponding Author) 13120 Dept. Global Business, Gachon Univ., 1342 Seongnam-daro, Sujeong-gu, Seongnam, Gyeonggi, Korea

email: jsyrena0923@gachon.ac.kr

3) (Associate Professor) 13916 Dept. Hotel Tourism, Daelim Univ., 29 Imgok-ro, Dongan-gu, Anyang, Gyeonggi, Korea

email: jszh1009@daelim.ac.kr 
combined total of RMB 1,270.5 billion. The amounts of investment raised through various equity refinancing channels are detailed in [Fig. 1].

As a method of refinancing for listed companies, private placement has far greater advantages compared to other refinancing methods[2]. The first of these is its convenience. When compared with stock allotment and public offerings, private placement offers obvious advantages, including lower barriers, an easier examination and approval process, lower issue costs, a faster turnaround, more flexibility in terms of policy, and so on[3]. Second, by using private placement, enterprises can obtain development funds quickly without facing additional pressure in terms of secondary market expansion in the short term, particularly by allowing large stockholders to raise stocks using high-quality capital as consideration. This allows productivity to be formed promptly, while also activating the un-listed assets of large stockholders[1]. Other benefits include fewer inflated transactions, higher-quality assets, a better financial situation, enhanced earning power, and so on. In theory, every effort is being made to support the development of listed companies. How effective are these measures in reality?

The convenience of private placement and the flexibility of its accounting policy, combined with the common dominance of a single stockholder, represents a major, ongoing problem in most Chinese listed companies. This is because such conditions are prone to breed certain negative behaviors among large stockholders owing to their pursuit of the superprofit made possible by private placement[4]. There are innumerable cases of large stockholders who abused private placements to obtain large profits. For example, in the case of Ningbo Construction (6O1789.SH), as part of a concerted private placement plan, 3 months before trading was suspended in 2011, the company's stock price fell from a high of RMB 11.77 to RMB 5.7, stabilizing at RMB 5.99. The average stock price continued to stay down at RMB 6.82 during the 20 days before suspension. Compared to the benchmark price of RMB 11.00, the stock price of Ningbo Construction fell by nearly $40 \%$ within 3 months. This kind of private placement seems reasonable and orderly, but actually serves to help save significant subscription costs for large stockholders. Consequently, the limit-up of Ningbo Construction after trading resumed benefited its large stockholders tremendously.

With the reviews conducted by governmental entities such as the Securities Regulatory Commission becoming increasingly strict, the risks associated with private placement refinancing has been assuming new forms. The main parties facing the risks of private placement in Chinese listed companies are no longer minority stockholders, but rather, large stockholders, investors who participated in the private placement, and the company's management. Since the risk of private placement is so large, why do so many listed companies use it for refinancing? 
In addition to the advantages discussed previously, a key reason for this preference for private placement is that it provides favorable terms for large stockholders' tunneling. Thus, it is the result of serious considerations regarding the refinancing risk and tunneling behavior of listed companies.

In the existing literature, most studies, both in China and abroad, concern the agent, announcement effect, or tunneling behavior of private placement. However, there are few studies regarding the risk of private placement, while none mention stakeholder risk in relation to tunneling behavior. This study adopts an innovative approach by analyzing the choice of a listed company's private placement in terms of both different stakeholders' refinancing risks and tunneling behaviors based on current studies.

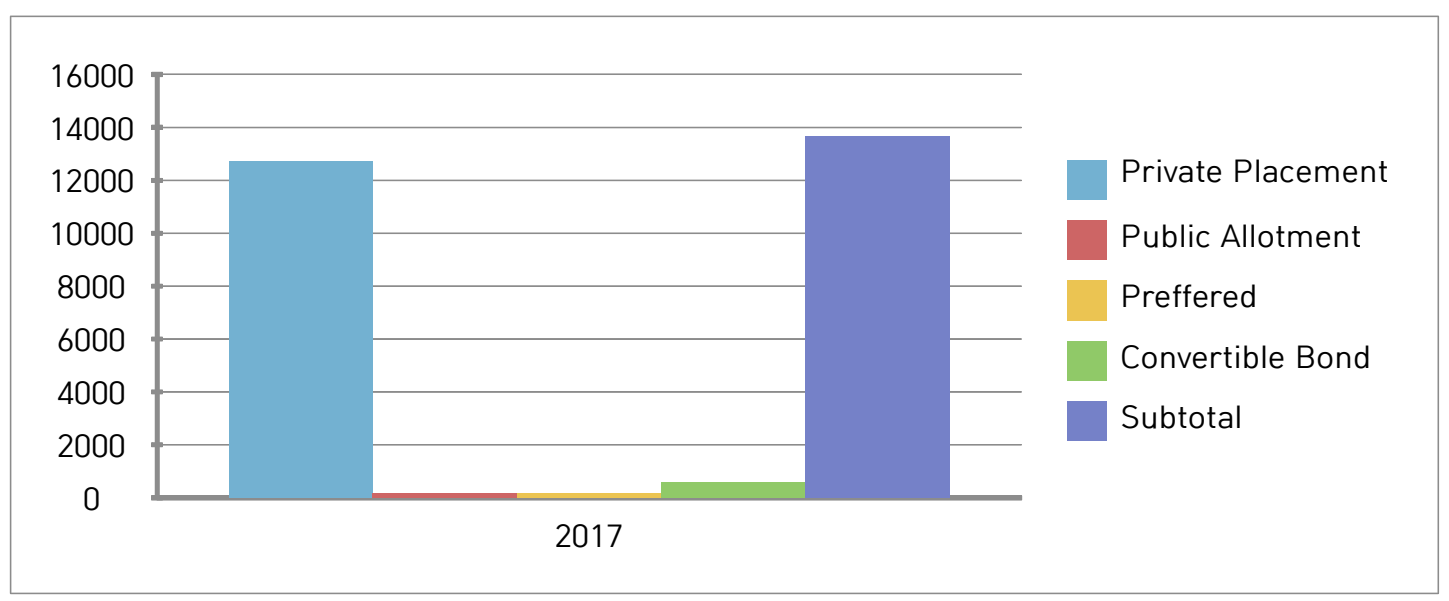

[Fig. 1] Amounts Raised through Equity Refinancing Methods (Unit: Billion)

Data Resource: GTA(Global Trade Analysis System) Database

\section{Theoretical Background and Literature Review}

Freeman first proposed the concept of a "stakeholder" in his book Strategic Management: A Stakeholder Approach published in 1983[5]. Freeman believed that every stakeholder's continuous support was indispensable for the development of an enterprise; therefore, the enterprise's operations and development should consider the benefits of all stakeholders and balance the various risks. Combining this approach with real-life situations, the main participants in listed companies' private placement plans are normally the original large stockholders, minority stockholders, new investors, and company management.

Principal - agent theory states that the division of proprietary rights and management rights 
means that the profits of the stockholder (principal) and the management (agent) are not always identical[6]. The root cause of principal-agent problems is the pursuit of profit. The risk of equity dilution for large stockholders mainly stems from the fact that, given the common situation of a sole Chinese stockholder playing a leading role in the company's operations and decision making, the professional manager usually chooses private placement to bring in outside investors by considering his or her own self-interest.

Some early researchers found that the company's operation and management rights were usually held by large stockholders, meaning that these large stockholders mostly decide the company's development. This makes it quite difficult for minority stockholders to participate in actual operations and management, as their rights are inevitably infringed by the large stockholders[7]. During this period, the principal-agent problem focused on how to control the conflict between the large and minority stockholders. As they hold the controlling right, large stockholders are always able to stay informed of key news, such as the benefits and risks of using private placement, the quality of private placement for raising assets, and so on, and are also able to act swiftly to protect their own profit or interests. However, this can only be done by infringing upon the rights of the minority stockholders.

According to asymmetric information theory, the information new investors have access to usually is good news, which is usually released by those listed companies who offered private placement stock to attract more investors[8]. It is difficult for new investors to obtain information about the actual operation status of the company. Thus, the information asymmetry regarding risk is considerable for new investors, when dealing with listed companies who can transfer the usage of funds after refinancing successfully through private placement, or who use their funds inefficiently to protect the profits of their investments.

\section{Theoretical Introduction to BOE's Private Placement}

BOE (Best Optoelectronics Enterprise Technology Group Co., Ltd) was founded in April 1993. It was formerly known as Beijing Orient Electronics, and produced equipment for the military (it was also called the 774 factory).

On January 12th, 2001, BOE was listed on the Shenzhen Stock Exchange. In 2002, BOE started to enter the comparatively backward LCD panel market. The innovation and development activities of a company always require large investments; moreover, the electronic industry is a very capital-intensive sector. Consequently, BOE's innovation and development plan entailed raising a huge sum of money. 
BOE is known as the "King of Financing" in the Chinese capital market. Upon being listed in 2001, BOE first issued 60 million stocks at the price of RMB 16.8/stock on the China B Stock Market through a public offering, raising RMB 0.975 billion. Since then, the main financing method for BOE has been private placement, an approach BOE has become inextricably linked with. By the first half of 2015, BOE had successfully offered private placement five times in the China A Stock Market, raising over RMB 70 billion in total.

In 2014, BOE became one of the top 10 best financing enterprises in the China A Stock Market, raising a total of RMB 45.713 billion. That raises another question, namely, what were the circumstances around BOE's private placement at this time?

BOE launched this private placement project after discussion on July 19th, 2013, and August 12th, 2013. It planned to offer 9.5 billion to 22.4 billion in new private placement stocks to investors at no lower than RMB 2.1/stock, with the aim of raising RMB 46 billion to help fund the enterprise's new display screen project. Based on internal decisions, the application of this non-public offering by BOE was processed by the China Securities Regulatory Commission on August 23rd, 2013, and was approved by the Issuance Examination Committee of the Securities Regulatory Commission on November 29th, 2013. By March 25th, 2014, BOE had issued 21.768 billion A Stock, raising RMB 45.713 billion in total. Excluding the total issuing costs (RMB 828.2949 million), the net amount of funds raised was RMB 44.885 billion.

In terms of financing, the total capital and currency subscription amount raised by BOE through private placement by this time were RMB 45.713 billion. Regarding the capital subscription aspect, Beijing State-owned Capital Operation and Management Center subscribed for shares worth RMB 8.533 billion via its subsidiary Beijing Best Optoelectronics Enterprise Display Technology's 48.92\% equity. The currency subscription amount was RMB 37.180 billion. Excluding the total issuing costs (RMB 828.295 million), the net amount of funds raised was RMB 44.885 billion.

\section{Stakeholders' Risk in BOE's Private Placement}

\subsection{Large Stockholders}

The main risks that large BOE stockholders faced were a low-price-offering risk, high-price-participation risk, controlling right risk, and so on.

When the private placement project was launched, China's stock market was suffering a downturn, meaning BOE could only attract investors at a comparatively low price. However, 
compared to BOE's price historically, this price was not low; it was actually at a comparatively high level. After the private placement, BOE's stock price would usually fall considerably, causing its market value to shrink continuously. All the investors who participated in the private placement would thus get stuck and would be unable to find a good time to quit. If BOE's performance is as per market expectations, or if the stock market remains stuck in a downturn, the risk for large stockholders to participate at a high price is also very high[9].

In this private placement, the top three targets were Beijing State-owned Capital Operation and Management Center, Hefei Jianxiang Investment Co., Ltd., and Chongqing Yuzi Guangdian Industrial Investment Co., Ltd. Among these companies, Beijing State-owned Capital Operation and Management Center represents Beijing state-owned capital, while Hefei Jianxiang and Chongqing Yuzi represent local state-owned capital.

After this private placement, the stock owned by the Beijing state-owned capital system and the Hefei state-owned capital system reached around 8 billion and 5 billion, respectively. However, the stock shares of both Beijing state-owned capital and Hefei state-owned capital visibly increased after this private placement, which may have represented a threat to large stockholders' controlling power of BOE. Consequently, BOE introduced Chongqing Yuzi Guangdian Industrial Investment Co., Ltd., which owned 3 billion stocks, as a new investor. This caused a more balanced structure with Hefei and Chongqing state-owned capital on one side and Beijing state-owned capital on the other, even though the controlling power remained with the Beijing State-owned Capital Committee.

\subsection{Minority Stockholders}

Compared to the diversity of large stockholders' profits, the profits of minority stockholders were quite different, as they are all put in one basket. Furthermore, minority stockholders were disadvantaged because they do not have much discourse power; therefore, the main risks of minority stockholders were the private placement price reduction problem, the principal-agent problem and so on[10]. During this private placement of $\mathrm{BOE}$, the minority stockholders suffered from many risks, such as private placement price reduction and private placement blindness.

\subsection{New Investors}

During the private placement of a listed company, the main risks that new investors face are 
higher-price subscription risk, lock-up period stock price reduction risk, asymmetric information risk, and so on[11]. In this private placement of BOE, the largest new investor was Chongqing Yuzi Guangdian Industrial Investment Co., Ltd.

\subsection{Company Management}

The main risks facing BOE management were operational performance stress, private placement stock price fall-on-debut risk, self-own power limitation, and risks of a demotion, salary reduction, or lay off, and so on[12].

\section{Analysis Regarding the Tunneling of BOE's Private Placement}

This study analyzes tunneling in terms of earnings management, private placement pricing, management subscription, and subscription method.

\subsection{Earnings Management}

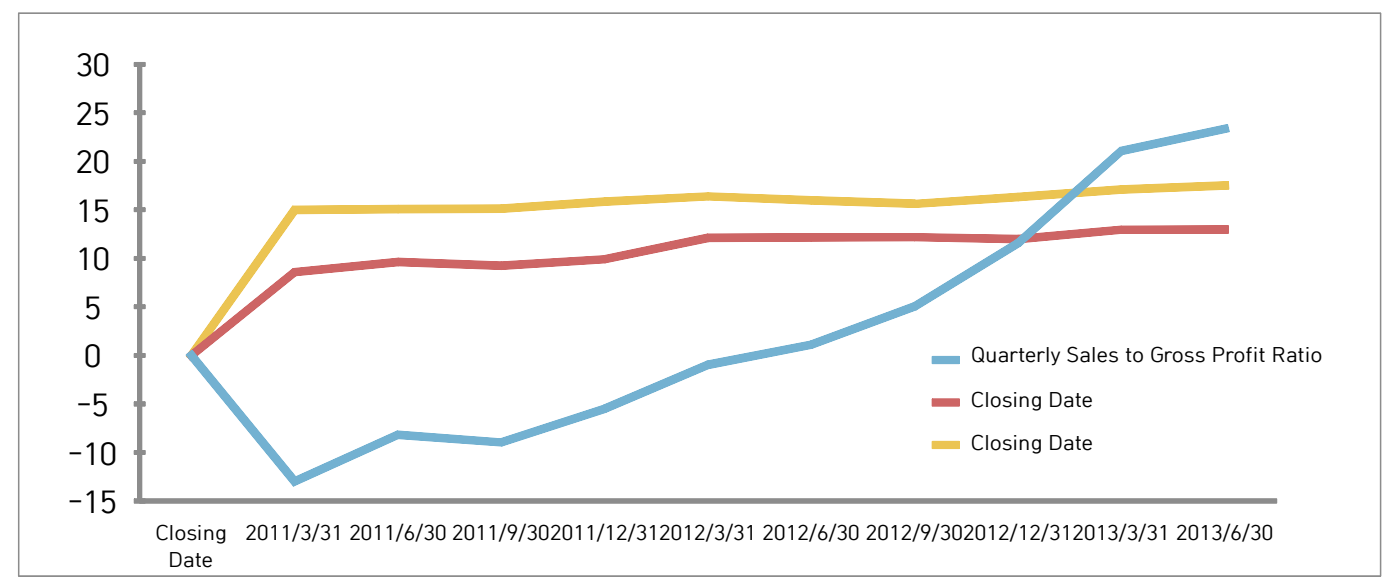

[Fig. 2] Quarterly Sales to Gross Profit Ratio of BOE

Data Resource: Consolidated by authors based on BOE's A stock annual reports

We can identify the potential benefit-managing behavior of $\mathrm{BOE}^{\prime} \mathrm{s}$ private placement around this time by the abnormal changes in the sales to gross profit ratio, sales profit ratio and asset impairment loss reserves, as well as the unmatched revenue and profit. 


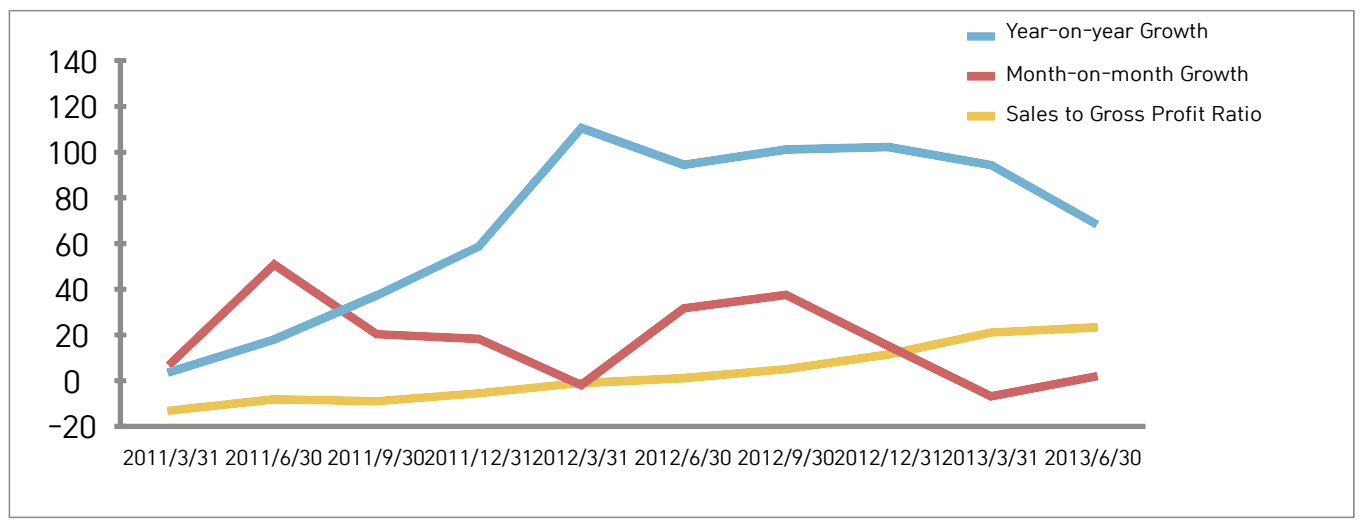

[Fig. 3] Quarterly Operating Revenue of BOE

Data Resource: Consolidated by authors based on BOE's A stock annual reports

[Table 1] Operating Revenue and Operating Profit of the Top 5 LCD Panel Manufacturers Globally

\begin{tabular}{|c|c|c|c|c|c|c|c|c|}
\hline \multirow[b]{2}{*}{$\begin{array}{c}\text { Listed } \\
\text { Company/Year }\end{array}$} & \multicolumn{2}{|c|}{2010} & \multicolumn{2}{|c|}{2011} & \multicolumn{2}{|c|}{2012} & \multicolumn{2}{|c|}{2013 Quarter 1} \\
\hline & $\begin{array}{c}\text { Revenu } \\
\mathrm{e}\end{array}$ & $\begin{array}{l}\text { Profit } \\
\text { Ratio }\end{array}$ & $\begin{array}{l}\text { Revenu } \\
\mathrm{e}\end{array}$ & $\begin{array}{l}\text { Profit } \\
\text { Ratio }\end{array}$ & $\begin{array}{c}\text { Revenu } \\
\mathrm{e}\end{array}$ & $\begin{array}{l}\text { Profit } \\
\text { Ratio }\end{array}$ & $\begin{array}{c}\text { Revenu } \\
\mathrm{e}\end{array}$ & $\begin{array}{l}\text { Profit } \\
\text { Ratio }\end{array}$ \\
\hline $\begin{array}{c}\text { BOE } \\
\text { (0.1 Billion) }\end{array}$ & 80 & $-28.90 \%$ & 127 & $1.20 \%$ & 257 & $-2.80 \%$ & 80 & $4.00 \%$ \\
\hline $\begin{array}{c}\text { Samsung LCD } \\
\text { Panel } \\
\text { (10 Billion } \\
\text { KRW) }\end{array}$ & 62,162 & $3.20 \%$ & 61,649 & $0.60 \%$ & 69,360 & $4.60 \%$ & 14,785 & $5.20 \%$ \\
\hline $\begin{array}{l}\text { LG LCD Panel } \\
\text { (10 Billion } \\
\text { KRW) }\end{array}$ & 23,695 & $0.60 \%$ & 23,902 & $2.00 \%$ & 22,738 & $2.40 \%$ & 5,173 & $0.60 \%$ \\
\hline $\begin{array}{l}\text { AU Optronics } \\
\text { (0.1 Billion } \\
\text { TWD) }\end{array}$ & 4,430 & $1.80 \%$ & 3,595 & $-15.20 \%$ & 3,630 & $-8.80 \%$ & 942 & $-1.40 \%$ \\
\hline $\begin{array}{c}\text { Innolux } \\
(0.1 \text { Billion } \\
\text { TWD }) \\
\end{array}$ & 4,737 & $-2.20 \%$ & 4,854 & $-13.10 \%$ & 4,715 & $-5.10 \%$ & 1,168 & $2.80 \%$ \\
\hline
\end{tabular}

Data Resource: Consolidated by authors based on BOE's A stock annual reports

[Table 2] Details of the Impairment Loss Reserves of BOE Assets (Unit: 0.1 Billion)

\begin{tabular}{|c|c|c|}
\hline Project & Year 2012 & Year 2011 \\
\hline Year Assets' Impairment Loss Reserves & 4.67 & 13.82 \\
\hline Assets' Impairment Loss Reserves & 12.54 & 15.64 \\
\hline Accounts Receivable Balances & 52.10 & 25.78 \\
\hline Year Bad Debt Reserves & 0.06 & 0.13 \\
\hline Bad Debt Reserves & 0.25 & 0.27 \\
\hline Inventory Book Balance & 29.93 & 27.44 \\
\hline
\end{tabular}




\begin{tabular}{|c|c|c|}
\hline Year Inventory Depreciation Reserves & 4.41 & 6.06 \\
\hline Inventory Depreciation Reserves & 3.24 & 6.28 \\
\hline Fixed Assets & 345.34 & 283.89 \\
\hline Year Fixed Assets Impairment Loss Reserves & 0.19 & 6.08 \\
\hline Fixed Assets Impairment Loss Reserves & 7.30 & 7.36 \\
\hline Bad Debt Reserves / Accounts Receivable & $0.50 \%$ & $1.00 \%$ \\
\hline Inventory Depreciation Reserves / Inventory & $10.80 \%$ & $22.90 \%$ \\
\hline Fixed Assets Impairment Loss Reserves / Fixed Assets & $2.10 \%$ & $2.60 \%$ \\
\hline
\end{tabular}

Data Resource: Consolidated by authors based on BOE's A stock annual reports

\subsection{Private Placement Pricing}

BOE's private placement took place on July 19th. BOE used the timing of its board meeting as a base for the timing of the placement, as this created greater scope for large stockholders and existing stockholders to infringe upon the benefits of minority stockholders. The price of BOE's private placement was RMB 2.10 /stock, which was way lower than the previous offerings of RMB 2.75 /stock, RMB 5.47/stock, RMB 2.4/stock, and RMB 3.03 /stock. As a result of BOE's improving performance, its stock price continuously rose before the private placement. However, BOE eventually chose to issue the private placement when the stock price was decreasing, rather than when it was still at its peak. This meant that the large stockholders who participated could subscribe for more stocks using the same assets, and also opened the door for them to conduct tunneling later.

\subsection{BOE Senior Management's Subscription}

BOE's private placement also included another rare phenomenon that cannot be ignored-the large subscription of BOE's management. Reviewing the previous instances of BOE's private placements, this was the first time that BOE's management participated. Without any doubt, they had the ulterior objective of cashing out after the lock-up period, despite putting out an official announcement claiming that the scheme had been launched "to maintain the high accordance of company management and stockholders, as well as the healthy and steady development of the company.

\subsection{Private Placement Subscription Method}

In China, existing stockholders can use assets as funds to subscribe to the private placement 
stocks offered by listed companies. The total amount of funds raised through this private placement by BOE was RMB 45.713 billion. One used equity exchange for funds, while another used creditor's right. These two methods potentially represent tunneling problems regarding asset evaluation.

\section{Conclusion and Suggestion}

Refinancing risks and tunneling behavior are both objective and relative in the context of the private placements of listed companies in China. For listed companies, the preference for private placement is the result of balancing the potential risks and benefits. In other words, there is possibility for different stakeholders to use tunneling during the private placement of listed companies when the profit it brings is larger than the risk. Thus, private placement-as an equity refinancing method-is favored by various parties, including listed companies, large stockholders, and agency investors.

The conclusions are as follows. The risks associated with private placement vary among different stakeholders (large stockholders, minority stockholders, new investors, management, etc.). Also, the main tunneling methods include earnings management, private placement pricing, subscription method, management subscription, reduction of stock scale, cash out in later phase, and so on.

For listed companies, the failure of private placement always means a failure to refinance, which has a huge impact on the existence and development of a company. The huge successes of BOE's widespread use of private placement is something of a miracle given the downturn in the whole private placement market in 2013. Based on the success of BOE, this article offers the following suggestions to listed companies: First, choose a financing and development mode that fits the company, maintain steady funding sources, and set a high-quality offering target. Second, respond by consolidating the company's strengths and improve its all-around abilities, such as innovation, competitiveness, and profit capability. Third, choose the right timing to issue the private placement. Fourth, take every opportunity to improve the confidence of the market and the related investors.

Although this paper conducts a case study on the BOE, a typical case of Chinese companies' private placement, but the data is relatively old because of the 2014 case, it may be of limited significance for the recent corporate private placement. Future research can be based on the recent case study of additional directional issuance of Chinese companies to analyze development trends and their models. 


\section{References}

[1] H. X. Cao, Analysis on the Status Quo and Motivation of Refinancing of Private Placement of Listed Companies in Henan Province, Guide to Business, (2015), Vol.8, pp.10-11.

[2] S. Y. Guo, M. Zhang, How does directional growth become a tool for large shareholders to gain control income? - A case study based on Chihong Zinc and germanium, Journal of Nanjing Audit University, (2013), Vol.4, pp.47-57.

[3] Y. R. Li, T. Li, An Analysis of the Motivation of Private Placement of Listed Companies, Technology \& Market, (2012), Vol.19 No.7, p.277.

[4] Y. Hu, T. Tian, Analysis of Interest Transfer Behavior in Private Placement of Listed Banks in China Based on the Case Study of Bank of Beijing, Friends of Accounting, (2014), Vol.31, pp.51-53.

[5] R. E. Freeman, Strategic management: A slakeholder approach, UK: Cambridge University Press, (1983)

[6] A. Berle, G. Means, Separation of Ownership and Control, Journal of Law and Economics, (1983), Vol.6, No.2, pp.301-325.

[7] S. Claessens, J. P. H. Joseph, Corporate Governance in Asia: A Survey, International Review of Finance, (2002), Vol.3, No.2, pp.71-103.

[8] G. A. Akerlof, The Market for "Lemons": Quality Uncertainty and the Market Mechanism, The Quarterly Journal of Economics, (1970), Vol.84, No.3, pp.488-500.

[9] D. Jiang, Analysis of Motives and Economic Consequences of Private Placement of Listed Companies, Entrepreneur World, (2010), Vol.10, pp.3-5.

[10] E. Q. Duan, T. H. Huang, Private Placement, Effect and Protection of Minority Shareholders' Interests- A Case Study of Chongqing Department Store, Accounting Learning, (2014), Vol.3, pp.66-69.

[11] C. Liu, Y. P. Ruan, K. Zheng, Does Private Placement Fall into the Trap of "Capital Curse"? - Study from the Perspective of Financial Constraints, Studies of International Finance, (2019), Vol.7, pp.87-96.

[12] G. Y. Zhao, Legal and Economic Analysis of Private Placement, Inner Mongolia Science \& Technology and Economy, (2017), Vol.10, pp.53-54. 